\title{
Aviation Management Role Models in the Deregulated Era
}

\author{
Edwin D. Phillips \\ Southern Illinois University Carbondale
}

\begin{abstract}
Aviation management students in both college and industry benefit by being provided credible role models. This research provides a methodical and valid approach to identify aviation industry leaders in the deregulated era. The research uses literature review of highly credible national awards and a unique survey of senior industry managers.
\end{abstract}

\section{INTRODUCTION}

\section{Background}

The challenge of managing in the deregulated era of aviation (starting October 24, 1978 ) is different than managing in the previous regulated era. The United States' General Accounting Office description of the changed environment is:

The Airline Deregulation Act of 1978 phased out the government's control over fares and service and allowed market forces to determine the price and level of domestic airline service in the United States...The airline industry has undergone significant change since the late 1970s. Industry capacity and passenger traffic have tripled. At the same time, the industry's profitability has become more cyclical, and the financial health of large legacy airlines has become more precarious. Legacy airlines emerged from a regulated environment with relatively high structural costs, driven in part by labor costs, including defined benefit pension plan costs (GAO, 2006, June 9).

In this difficult business climate the aviation industry has had some very public turmoil among its leaders. CEO Jim Goodwin was forced out of United (Embattled head of United Airlines is ousted, 2001, October 29). Don Carty was forced to resign as Chairman of American (Reed, 2003, April 25). Boeing lost two CEOs. Phil Condit resigned in 2003 under pressure associated with irregularities with an Air Force contract and in 2005 Harry Stonecipher resigned under pressure for perceived personal misconduct (Isidore, 2005, March 7).
These individuals will not appear in the aviation management literature as positive role models. But, role models are important in the learning process. Professional career planners indicate role models are beneficial for new employees and students (Ezarik, 2004; Verlander, 1985). This suggests instructors in the aviation management field teaching new employees or college students should provide role models to their students.

The industry has positive role models from the era before deregulation. In the aviation history section of An Introduction to Air Transportation individuals are labeled as "the men who became the giants of the industry" (Wells \& Wensveen, 2004, p. 46). Individuals listed are William A. Paterson, United Airlines; C.E. Woolman, Delta; Eddie Rickenbacker, Eastern, and Jack Frye, TWA. The leadership role of these individuals occurred in the early years of aviation starting in the 1930s. No individuals are identified as aviation leaders in the deregulated era.

Kaps (1997) discusses the history of the air transport labor relations environment. He separates the periods before and after deregulation but offers no suggestion as to individuals responsible for any positive industry trends since deregulation. These two nationally popular college texts are indicative of the situation that current aviation role models in the deregulated era have not been clearly identified in the aviation education literature. This situation leads to the research question: Who are the aviation industry leaders in the deregulated era?

\section{Perspective}

This project is limited to the aviation industry in the United States. "Aviation 
industry" refers to commercial airline, corporate/business aviation or airport operations and aviation manufacturing and service companies. This view allows inclusion of possible role models from the FAA or other government agencies directly involved in civil aviation. No effort has been made to identify leaders in military aviation, individuals responsible for aircraft performance records, those primarily associated with technological development or politicians/legislators in the role of setting regulations or state/Federal policy.

\section{Research method}

Research for this project involves:

1. Literature review of information regarding role models,

2. Identification and review of national aviation sources that recognize management performance,

3. Identification and review of national business sources that recognize performance by aviation managers,

4. Personal interviews of a small group of very experienced airline managers to determine if they could and would identify industry leaders in the deregulated era,

5. An anonymous survey of another larger group of experienced senior aviation managers.

If steps 2 through 5 consistently identify the same individuals the results, based on the naturalistic research philosophy of Lincoln and Guba (1985), are valid. They indicate that when results start repeating themselves sample size is adequate and the results can be considered valid. Permission for research involving human subjects was obtained from the appropriate source before beginning this research.

\section{IDENTIFYING AVIATION MANAGEMENT ROLE MODELS}

\section{The value of role models}

Merriam - Webster online dictionary (2006a) defines a role model is an individual who will be imitated by others; Worldreference.com (2006) indicates a role model is someone worthy of imitation; and Allwords.com (2006) indicates it is someone who sets an example to follow. A common synonym is hero. A hero is an individual admired for his or her qualities (MerriamWebster online, 2006b). A full review of the role model literature requires starting with Aristotle's On Rhetoric and his comments on emulation of behavior (Kristjánsson, 2006). Such thoroughness seems inappropriate for this effort. What follows, however, offers a consistent voice in support of the benefit of using the role model concept in the education process.

"Organizational behavior and career theorists have suggested that identification with role models is critical to individual growth and development” is Krumboltz's view (as cited in Gibson, 2003, p. 1). "Motivational and developmental psychology stresses the need for role models for developing individuals" (Murphey, 1996, p. 21). The Vice Commander of the Air Force Air Education and Training Command told a high school audience to choose role models who can serve as positive examples for them to follow (Agency Group 9, 2002). This sentiment is echoed by an Air Force Chief Master Sergeant writing from Iraq stating that role models are vital and necessary (Erwin, 2006). "Today's kids need heroes, but not the kind you'll see in the movies or on TV. They need role models who can help with worthy activities" (Titus, 2000, p. 3). The editor of Machine Design states "My role models taught me about management" (Khol, 2005, p. 10). "Role models can change our beliefs about what we have the capability to be and to accomplish" (Sehgal, 2004, p. 1).

Jim Collins is the author of acclaimed management books Built to Last and Good to Great...Why Some Companies make the Leap and Others Don't. In an interview he states, "We learn by stories and role models, and we need models to operate with" (Manville, 2001, 33). In their Leadership: A communication perspective text, Hackman and Johnson (1996) provide suggestions for shaping organizational culture. Step 4 is "Deliberate role modeling, teaching and coaching” (p. 215). Kouzes and Posner (1995), who have been recognized for their work on leadership, discuss the importance of learning from others. They indicate, “...we can learn from people without having a 
relationship with them. As often as people mention learning from managers, peers, or mentors, they mention outside role models” (p. 331).

In summary, identifying role models (or heroes) is a recommended and accepted technique to aid a student's education. "...educators are in a prime position to encourage young people to understand and identify with true heroes and the values they embody" (Sanchez, 2000, 12). This concept is valid if the student is in grade school, college or an industry supervisor.

\section{Criteria for an aviation industry manager role model}

Identifying individuals who might be aviation industry role models in the deregulated era requires locating or developing criteria on which to base a selection. A search of the aviation management literature resulted in finding no published criteria for an aviation industry role model. Yet, various individuals such as Patterson at United and Frye at TWA, mentioned by Wells and Wensveen (2004), have been accepted as industry leaders without argument. Their backgrounds therefore serve as a guide. Another guiding characteristic is the description of the management process which involves the achievement of targeted organizational objectives and the processes of planning, leading, organizing and controlling as described in Phillips and Kaps (2005). This assists in identifying the managerial versus other type roles in aviation history. The author's personal twenty-nine-year management career in a major airline that spans the regulated and deregulated era also helps form the criteria. These three influences - (1) agreed upon early aviation leaders, (2) a description of management, and (3) personal managerial experience - guide in formation of the proposed criteria.

To be considered an aviation industry managerial role model a person must substantially meet these four criteria:

Criteria \#1: Serves (served) in management positions directly related to producing, selling, or operating aircraft seats and cargo space in the public sector.
Criteria \#2: Employees, customers, owners, shareholders and/or the general public depend(ed) on these individuals to ensure their companies or specific organization performed well. These two criteria exclude individuals such as:

- An individual known predominantly for personal performance such as Steve Fossett who has set recent world records in a balloon and airplane.

- Those known for general performance as a pilot such as Brigadier General Chuck Yeager.

- Politicians like Senator Barry Goldwater who has been recognized "for serving as an articulate spokesman for American aviation and space in the Congress and throughout the world” (NAA, 2006a, Barry Goldwater).

- Engineers or technological innovators such as Burt Rutan designer of unique aircraft and spacecraft.

These individuals all have a place in aviation history, but not as "industry managers."

Criteria \#3: Performed over an extended period of time (i.e. five or more years).

Criteria \#4: Has received national recognition from a respected source.

\section{Identifying possible role models through national awards}

The fourth criteria, has received national recognition from a respected source, proves to be the most beneficial manner of identifying possible candidates. The seven sources selected were chosen for their probable validity. They are divided into two categories. The first three are primarily aviation sourced, and the last four are based on general managerial/leadership sources.

Source \#1: Wings Club Distinguished Achievement Award winners - Appendix A This private club was formed in 1942 in New York City for the purpose of supporting aviation (Wings Club, 2005). Juan Trippe of PanAm and Eddie Rickenbacker were early board members. Current officers include the Chairman of AirBus North America, Chairman of Air Tran, President of JetBlue, and Boeing's Vice President of Sales, Marketing and In-Service Support for the 787 (Wings Club, 2006). The Club's interest includes military aviation, aerospace, general 
aviation, commercial aviation, etc. Each year an Achievement Award is presented to a distinguished member of industry. In 1978 the award was presented jointly to W. A. Patterson (United Airlines), Robert F. Six (Continental Airlines), Cyrus R. Smith (American Airlines) and Juan Trippe (PanAm). (Job titles for individuals listed in appendices are those included in the original listing and have not been adjusted to accurately reflect current positions or to highlight prior positions of possible importance.)

The annual selection process is described by Harris Herman, General Manager of The Wings Club (personal communication, March 16, 2006). The process involves the Awards Chairman and club President discussing possible candidates and soliciting names from the Club's Executive Committee and other Board members. A short list is developed and presented to the Board who votes on the nominee. The nominee is contacted to determine if he/she will accept. The credibility of this award is suggested by the 24 Board members who approve the selection. Current members include Gordon Bethune, Chairman of Continental Airlines; David Barger, President and COO of JetBlue; Jim Guyette, President and CEO of Rolls Royce of North America; Dr. George H. Ebbs, Jr., President of Embry-Riddle Aeronautical University, etc.

Source \#2: Wright Brothers Memorial Trophy Past Recipients - Appendix B. The Aero Club of Washington (District of Columbia) was founded in 1909 (Aero Club, 2006). Knowing the diversity among the officers helps explain the club which serves as a monthly gathering of a wide mix of 500 key aviation industry representatives. The current Club president is a JetBlue executive. The past three Aero Club presidents are from three different organizations, the National Association of State Aviation Officials, the American Association of Airport Executives and the National Business Aviation Association. The Club is the host for the annual Wright Brothers Memorial Trophy which is awarded by the National Aeronautic Association (NAA) (Nancy Hackett, Executive Director of the Aero Club of Washington, personal communication, March 16, 2006).
The NAA is the oldest national aviation association in the United States. Each year, starting in 1948, the Club awards the Wright Brother's trophy "to a living individual for significant public service of enduring value, as a civilian, to aviation in the United States" (NAA, 2006b). Nominations for the Wright Brothers Memorial Trophy may be made by the general public. The Selection Committee is appointed annually by the President of the NAA and consists of seven members, which includes the President, Chairman, Administrator, or a representative of each of the following:

National Aeronautic Association

National Aeronautics and Space Admin.

Air Transport Association

Aerospace Industries Association

American Institute of Aeronautics and Astronautics

Aero Club of Washington

The Aviation Press.

The credibility of the award relates to those involved in the selection process. This group is clearly a knowledgeable, diverse and respected cross-section of the aviation industry.

Source \#3: W. A. Patterson Lecturers, Northwestern University Transportation Center -Appendix C W.A. Patterson was "a life trustee of Northwestern and was instrumental in the establishment and strategic leadership of the Transportation Center.” In 1978 the William A. Patterson Distinguished Chair in Transportation was established. Starting in 1980 an annual Patterson Lecture is held. A faculty committee participates in selection of the speaker. Criteria include recognition of the speaker as a transportation expert or leader, as well as timeliness and variety of topic (Diana Marek, Assistant Director, Northwestern University Transportation Center, personal communication, March 17, 2006). The Northwestern University Transportation Center has and does hold a respected position within academia. Since selection of speakers is primarily limited to faculty and staff of the university and because "timeliness and variety of topic" are part of the criteria this is an award with a high level of credibility but one that perhaps does not rise to the same level as the two prior awards. 
Source \#4: CNN Top 25: Most influential business leaders of the last 25 years - Appendix $\underline{D}$ CNN selected a "distinguished panel” of "experts" to select these top 25 business leaders from the last 25 years (CNN.com, 2005 June 19). CNN does not specify the specific criteria used to rank the business leaders. It seems reasonable to accept CNN's claim that appropriate individuals were used to develop this list and that the results are credible. CNN would not risk the embarrassment of an inappropriate process or selection. Other than perhaps the inclusion of Ted Turner on the list, there appears to be no possible political motivation in the selections. The 25 year time period is unspecified but covers approximately 1980 - 2005, essentially the entire period since deregulation. Those selected represent a wide range of recognized business persons.

Source \#5: Harvard Business School $20^{\text {th }}$ Century Great American Business Leaders Transportation (Harvard Business School, 2006a)-Appendix E

Source \#6: Harvard Business School 20 Century Great American Business Leaders Automotive and Aerospace (Harvard Business School, 2006b) - Appendix F Both Appendix E and $F$ are part of an effort by members of the Harvard Business School Leadership Initiative to identify “...20 $0^{\text {th }}$ century men and women whose business leadership shaped the ways that people live, work, and interact" (Harvard Business School Leadership Initiative, 2006, $20^{\text {th }}$ Century Great American Business Leaders).

Source \#7: Top 50 Business Leaders of the $20^{\text {th }}$ Century - Appendix $G$ The above three lists all stem from the same research conducted for In Their Time: The Greatest Business Leaders of the Twentieth Century (Nohria \& Mayo, 2005). The book is a highly credible summary of extensive research evaluating managerial performance. The research involved surveying 7,000 American business leaders to determine their opinion about their peers. Individuals considered had to have been a chief executive officer (CEO) in a single company for a minimum of five years. (It is coincidental that the selection criteria included earlier in this article and Nohria and Mayo's research both are based on a five-year minimum period of performance.) Successful financial performance of the company, as measured by one of four specific financial metrics, is also a requirement. The authors also consulted 17 other significant research projects evaluating performance by individual business leaders.

Appendix $\mathrm{G}$ is the Top 50 of the 100 leaders identified through Nohria and Mayo's (2005, p. xxii) research. Only the top 50 are used here for convenience. This list of those in $51^{\text {st }}$ through $100^{\text {th }}$ place includes one aviation industry person, Juan Trippe, in position 91.

Some may argue that Time Magazine, Fortune, Aviation Week \& Space Technology and other sources that provide annual awards or lists of business leaders should also have been used. The author has no evidence that using such lists would increase the validity of the response provided by the above seven lists.

\section{SELECTING ROLE MODELS}

Table 1 lists the 13 names of aviation leaders of the deregulated era that are included in one or more of the sources/appendices. An " $X$ " under the letter of the appendix indicates the individual's name is included in that list. The company affiliation and calendar time-span have been added where not included in the original listing. Because of the differing qualifications between Appendices $\mathrm{E}$ and $\mathrm{F}$, the maximum number of opportunities for recognition is six - only achieved by Kelleher. Seven of the above 13 individuals shown in Table 1 have received recognition from only one source. They are excluded from further consideration.

The six individuals listed in Table 2 are included in a minimum of two and maximum of six lists. They are listed in rank order based on number of awards or lists. Both Bethune and Lorenzo appear on only two lists. The two lists include one of the preeminent aviation groups (either the Wings or NAA) and one of the national business leaders lists. This seems adequate justification for them to be included in a final list. 
Table 1. Summary of national recognition of aviation leaders of the deregulated era.

Appendices

\begin{tabular}{|l|l|l|c|c|c|c|c|c|c|}
\cline { 2 - 7 } \multicolumn{1}{l|}{} & Name & Company and executive tenure & A & B & C & D & E & F & G \\
\hline 1 & Gordon Bethune & Continental 1994 - 2004 & X & & & & X & & \\
\hline 2 & Donald Burr & People Express 1980 - 1986 & & & & & X & & \\
\hline 3 & Edwin I. Colodny & US Airways 1975 - 1991 & & X & & & & & \\
\hline 4 & Robert L. Crandall & American Airlines 1985 - 1998 & X & X & X & & X & & \\
\hline 5 & John C. Emery, Jr. & Emery Air Freight 1968 - 1987 & & & & & X & & \\
\hline 6 & Richard Ferris & United Airlines 1975 - 1987 & & & X & & & & \\
\hline 7 & Herbert D. Kelleher & Southwest Airlines 1971 - present & X & X & X & X & X & & X \\
\hline 8 & Francisco A. Lorenzo & Texas Air Company 1972-1990 & & & X & & X & & \\
\hline 9 & David Neeleman & JetBlue 2000 - present & & X & & & & \\
\hline 10 & Frederick W. Smith & Federal Express 1971 - present & X & X & X & & X & & X \\
\hline 11 & Harry Stonecipher & Boeing Company 1997-2002, 03-05 & X & & & & & & \\
\hline 12 & William W. Winpisinger & $\begin{array}{l}\text { President International Association of } \\
\text { Machinist and Aerospace Workers 1977 - }\end{array}$ & & X & & & & \\
& & 1989 & & & & \\
\hline 13 & Thornton A. Wilson & Boeing Company 1969 - 1986 & X & X & & & X & \\
\hline
\end{tabular}

Table 2. Aviation Leaders in the Deregulated Era based on national recognition.

\begin{tabular}{|l|ll|}
\hline \multicolumn{3}{|l|}{ Aviation Leaders in the Deregulated Era } \\
\hline 1 & Herb Kelleher & (6) (indicates number of awards) \\
\hline 2 & Frederick W. Smith & $(5)$ \\
\hline 3 & Robert L. Crandall & $(4)$ \\
\hline 4 & Thornton A. Wilson & $(3)$ \\
\hline 5 & Gordon Bethune & $(2)$ \\
\hline 6 & Francisco A. Lorenzo & $(2)$ \\
\hline
\end{tabular}

\section{INDUSTRY VOICES}

\section{The Valentine weekend experiment}

If you're in northern San Diego County over Valentine's Day weekend you'll find a group of now mostly retired airline people playing golf. In 2005 ten “airline guys” (it's traditionally been an all male gathering) plus their friends attended for the $36^{\text {th }}$ year. All ten individuals are currently or were previously in managerial positions for one of the world's largest airlines, several for more than forty years. Their varied backgrounds include positions with system-wide responsibilities in various areas such as consumer relations, employment, onboard planning, contract negotiations, etc. Job titles held include vice president, director, and general manager. Airport operations managed by these individuals include small line stations and major U.S. and international hub stations. Some left the core airline and went on to significant responsibilities with other airlines (i.e. chairman of a major regional) or related industry jobs. In summary, these individuals have much industry experience and, fortunately, they are better managers than golfers.

Either singularly or in groups of two or three, each was presented the same story. "I'm doing some research for a project. Think about our time in the industry since deregulation started. Who are the key industry leaders? Who should be put in the aviation history books as 
being the best aviation managers? Said another way, who should I offer to my students as role models, as industry leaders?”

The consistent initial response was silence followed by something like, "I don't know if I can.” Then, as the brain shifted from golf to work, names like Donald Nyrop (Northwest), W. A. Patterson (United), C. R. Smith (American) and Juan Trippe (Pan Am) were offered with the comment that they were great but came before deregulation. After a bit more reflection the comment would be something like, "Probably Crandall. He did a great job at American. Oh, yeah, and the Southwest guy, Kelleher. That airline has done great. And Lorenzo had a helluva impact but not the best of outcomes. So, maybe Crandall and Kelleher?” The majority of responses include one or both of these individuals.

No other name was mentioned with any consistency. Dick Ferris (United) was mentioned a few times as an individual who led the fight for deregulation. "That JetBlue guy (David Neeleman), and Bethune at Continental" were mentioned by one or two individuals. No other names were offered. Perhaps in support of a friend's efforts, several responses included the unsolicited comment, "That's a good question."

Reflecting on the answers during the trip home from the outing it seemed that the question was legitimate and answerable. The five individuals identified as possible role models were Crandall, Kelleher, Bethune, Neeleman, and Ferris.

\section{The "former" group survey}

One of the many groups that use the Internet to stay abreast of a common interest is about 180 former senior managers of a major international airline. (For convenience these individuals are referred to as the former group.) Members must have been in a senior management position at that airline and had at least a three year separation from the company before joining the email list. (This author is one of those members.)

The business background of members of the former group make them uniquely qualified to answer research questions about industry managers. The members of the former group include past presidents, senior officers, directors and managers, many of which are known nationally within and outside the aviation industry. Their experience covers the spectrum of major functional areas: sales, marketing, finance, planning, law, operations, flight, onboard service, etc. A significant number of these individuals have worked at more than one aviation company. Some have prior or current experience in a wide variety of areas that support airline operations including security, cabin refurbishment, tourism, consulting, manufacturing, etc. Several members are currently chief executive officers of national aviation related companies other than airlines.

A significant number of the individuals on this email list have interacted personally with industry leaders such as Crandall and Kelleher. They have worked with them at another airline or on an industry task force or perhaps an Air Transport Association (ATA) committee. Essentially every member of the former group has been or is in daily competition with and frequently had or has an opportunity to observe first-hand the management style of industry leaders. Therefore names mentioned in response to the survey questions are not just people who the respondents have read about in the news. If they weren't known personally, their names and or strategies were often discussed in staff meetings, around tables in the employee cafeteria and even on the golf course.

Group members were asked by email to complete an online survey. Sixty-two percent of the respondents indicate an airline background. The remaining 38\% identify themselves, spread almost equally, among the categories of government, aircraft manufacturing, airport operations, aviation service organizations, and one media representative. This demonstrates the diverse career pattern taken by individuals who at one time worked for an airline.

Eighty-one percent were able to identify "Who is the most influential manager in aviation since deregulation?” Thirteen percent said no one deserved that recognition and six percent didn't know who it should be. A second question asked for the name(s) of "Other individuals that should be on the list of top managers during the deregulated era of aviation." Results are shown in Table 3. Individuals receiving a single recommendation 
are not included. Examples are Jerry Atkin (SkyWest), Bruce Kennedy (Alaska), Jane Garvey (FAA), Joe O’Gorman (Aloha, Frontier, Reno Air, United and DHL), and Howard Putnam (United, Southwest, and Braniff).

\section{Analysis of industry voices}

The five names identified during Valentine day interviews appear on the list of individuals identified by the former group. Results from the experienced former group closely mirror the results found in the national awards. A surprising omission is Smith of FedEx. The former group is from a predominant passenger carrier, but many of the individuals have been responsible for results in the cargo end of the business. The failure of this group to mention
Smith is not justification to question his inclusion on a list of aviation leaders during the deregulated era.

Wilson of Boeing is not mentioned by the former group of predominantly operational versus manufacturing managers. However, several of the members of this former group spent much time traveling to Boeing's facilities during aircraft purchase and development meetings. Some of these contacts were at the senior executive level. My sense is this group of primarily airline people fail to give the same consideration to Wilson's record as have others in the aviation community.

Table 3. Survey results of the former group.

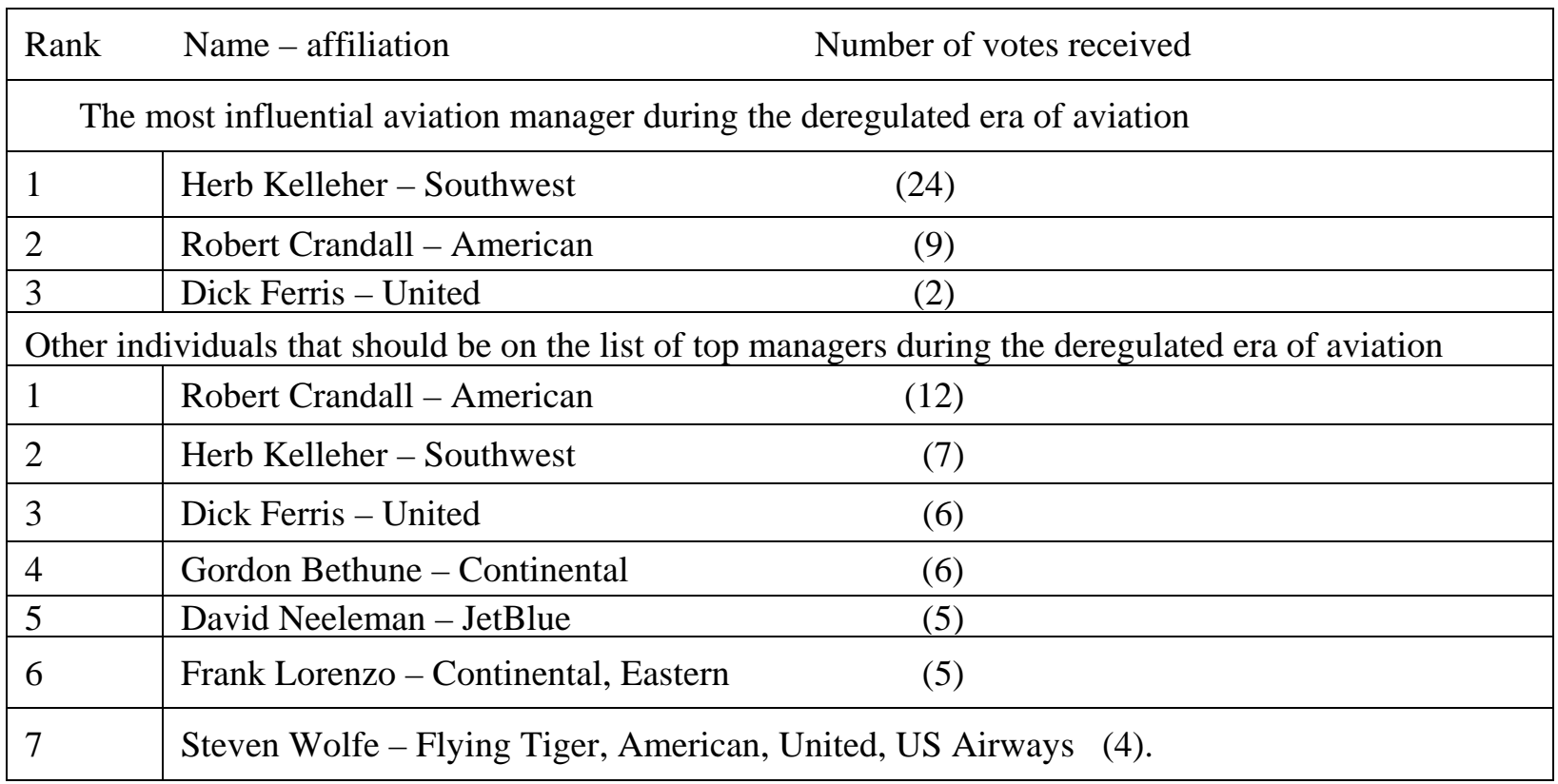

Neeleman is mentioned by the former group and is one of the Patterson Lecturers. JetBlue is now only six-years old and long term performance of both the company and Neeleman is still being determined. His business strategies continue to receive attention from the media and competitors (i.e. low-cost operation with highcost aircraft interiors and amenities such as all aircraft equipped with live $\mathrm{TV}$, reliance on automation, openness of information sharing with employees, etc.). It will be difficult to discuss aviation in the early $21^{\text {st }}$ Century without close attention to JetBlue. It is likely, depending on the track performance of JetBlue in the next few years, that Neeleman will eventually be recognized by the Wings Club and or NAA. This view results in a conclusion he should be added to a final list of key aviation managers.

Dick Ferris is mentioned in the Valentine weekend experiment and the former survey. He is also the first Patterson Lecturer (which was probably influenced because United wrote a large check to help fund the W.A. Patterson Chair). But, he is not listed on any of the other national lists. He is an individual worth study, but does not belong on the role model list. He is 
known in the industry as one of the key leaders for deregulation. However the 1985 ALPA pilot strike and United's aggressive but unsuccessful efforts to break the strike caused Ferris' subsequent departure from the airline prior to achieving his long-term personal goals of creating a multifaceted travel company (airline, hotels, rent-a-car, etc. conglomerate).

Steven Wolfe is mentioned only in the former group survey and not on any of the national award lists. His absence from any of the lists precludes his identification as a role model. Yet he is an excellent subject for research by individual students. His personal business history may be one of the more interesting and financially successful CEO careers in the industry (if an investor bought and sold at the proper times). His vision and leadership created the world's largest employee owned company, United. But it was an experiment that failed in the long-term. His varied leadership positions at a variety of airlines may make it difficult for him to be easily compared with a Kelleher or Crandall who have long roots with a singular company.

\section{CONCLUSION}

\section{The final list}

The three data sources - the award search, the interviews and the survey results - provide repetitive results complimentary results which create a meaningful list of aviation industry role models in the deregulated era. They are listed in Table 4 in alphabetical order. The repetition and consistency of results from the three sources meet Lincoln and Guba's (1985) test of validity.

\section{Personal characteristics}

An obvious question about these role models is "What have they done and how have they done it which results in personal and/or organizational achievement deserving of recognition?” Mayo and Nohria (2005) provide detailed information about the performance characteristics of managers and leaders. The various awards have some level of published criteria for selecting winners. The former group was asked to and provided explanation why they recognized individuals as an influential manager.
A long list of what is easily developed. Examples include the long-term financial success of Southwest, creation of innovative marketing concepts such as frequent flyer programs under Crandall's leadership at American, significant business turn-around as achieved by Bethune at Continental. Lorenzo created a large aviation empire and broke new ground in labor relations.

How these accomplishments were achieved is important. I refer to this as the individual's management style. Crandall's reputation among those in the industry is that of a tough boss. Kelleher has used a folksy image while hiding an extremely effective intellect. He epitomizes the view that the boss's job is to take care of the employees who in-turn will take care of the customer. Frank Lorenzo's managerial approach is often described with words that do not belong in an academic article.

The what and how questions which are only briefly addressed here are the basis for additional and meaningful research. A thorough investigation requires an extensive effort that does not fit within this article. But, one or more of you who read this are encouraged to accept the challenge of investigating these issues as a continuation of this project with the view of helping students identify why the individuals you or future textbooks identify are role models including both what is it they have accomplished and especially how have they achieved those accomplishments.

\section{Summary}

Providing students with role models is a meaningful, beneficial academic technique. The aviation business changed in 1978 and processes that worked in the regulated era require different approaches today. Aviation management students in college and industry will benefit by studying aviation role models of the deregulated era.

Seven established aviation role models are identified. All the individuals are living, and, most are still actively involved in the industry in some capacity. For example, Smith still leads FedEx. Crandall has retired from American but writes editorial opinion pieces about the industry and is now Chairman and CEO of Pogo (a new air-taxi service using very light jets) (flypogo.com, 2006). Specific study of what 
these seven have accomplished and how they have accomplished is a desirable expansion of this research.

The information contained here only has value if it is shared. You are encouraged to share this information with whomever you consider might benefit. That includes students, peers, or even the general public. Our industry, which continues to face service and financial challenges, has examples of successful, strong leadership and we should use every opportunity to publicize that fact.

Table 4. Aviation manager role models in the deregulated era.

\begin{tabular}{|l|l|l|}
\hline \multicolumn{2}{|l|}{ Name } & Affiliation \\
\hline 1 & Gordon Bethune & $\begin{array}{l}\text { Former Chairman of Continental } \\
\text { Airlines }\end{array}$ \\
\hline 2 & Robert L. Crandall & Former Chairman of American Airlines \\
\hline 3 & Herb Kelleher & Executive Chairman Southwest Airlines \\
\hline 4 & Francisco A. Lorenzo & Former Chairman Texas Air Corporation \\
\hline 5 & David Neeleman & Chairman JetBlue \\
\hline 6 & Frederick W. Smith & Chairman Federal Express \\
\hline 7 & Thornton A. Wilson & Former chairman Boeing Company \\
\hline
\end{tabular}




\section{REFERENCES}

Aero Club. (2005). About Aero Club of Washington D.C. Retrieved March 29, 2006 from http://www.aeroclub.org/about/aeroclub.htm

Agency Group 9. (2002, February 12). Role models, education keys to success. FDCH Regulatory Intelligence Database, U.S. Department of Air Force. Retrieved February 6, 2006 from http://web17.epnet.com/deliveryprintsave.asp?tb=1\&_ug=sid+D4887B65-9122-4DC7-83A9-0

Allwords.com. (2006). Role model. Retrieved March 30, 2006 from http://www.allwords.com/wordrole\%20model.html

CNN.com. (2005 June 19). Top 25: Influential business leaders. Retrieved July 21, 2005 http://www.cnn.com/2005/US/02/28/cnn25.top.business/

Erwin, J. B. (2006, January 19). Nurturing the future, grooming Airmen for success. Air ForceLink. Retrieved February 6, 2006 from http://www.afmil/news/story.asp?id=123014005.

Ezarik, M. (2004). Six Steps to Success. Career World, 32(4), 6 - 12.

Flypogo.com. (2006). Our story. Retrieved March 31, 2006 from http://www.flypogo.com/story.html

Freiberg, K. (1998). Nuts! Southwest Airline’s crazy recipe for business and personal success. New York: Broadway Books.

GAO. (2006, June 9). Abstract. Airline Deregulation: Reregulating the Airline Industry Would Likely Reverse Consumer Benefits and Not Save Airline Pensions, GAO-06-630. Retreived July 4, 2006 from http://www.gao.gov/docsearch/abstract.php?rptno=GAO-06-630

Gibson, D. E. (2003). Role Models: Reinvigorating a developmental construct in career theory. Academy of Management Annual Meeting Proceedings 2003. Retrieved March 16, 2006 from EBSCO Information Services.

Hackman, M. Z., \& Johnson, C. E. (1996). Leadership: A communication perspective (2 ${ }^{\text {nd }}$ ed.). Prospect Heights, IL: Waveland Press.

Harvard Business School. (2006a). 20 $0^{\text {th }}$ Century great American business leaders - Transportation. Retrieved March 29, 2006, from http://www.hbs.edu/ leadership/database/industry/\#Transportation.

Harvard Business School. (2006b). 20 $0^{\text {th }}$ Century great American business leaders - Automotive and aerospace. Retrieved March 29, 2006, from http://www.hbs. edu/leadership/database/industry/\#Automotive\%20and\%20Aerospace.

Harvard Business School Leadership Initiative. (2006c). 20 $0^{\text {th }}$ Century great American business leaders. Retrieved March 29, 2006 from http://www.hbs.edu/leadership/database/index.html.

Isidore, C. (2005, March 7). Boeing CEO out in sex scandal. CNNMoney.com. Retrieved July 4, 2006 from http://money.cnn.com/2005/03/07/news/fortune500/boeing_ceo/

Kaps, R. W. (1997). Air transport labor relations. Carbondale, IL: Southern Illinois University.

Khol, R. (2005, September 1). Editor's Comment: My role models taught me about management. MACHINE DESIGN, p. 10.

Kouzes, J. M., \& Posner, B. Z. (1995). The leadership challenge: How to keep getting extraordinary things done in organizations. San Francisco: Jossey-Bass.

Kristjansson, K. (2006). Emulation and the Use of Role Models in Moral Education. Journal of Moral Education, 35(1), 37- 49.

Lincoln, Y.S., \& Guba, E.G. (1985). Naturalistic inquiry. Newbury Park, CA: Sage. 
Manville, B. (2001, Fall). Good to great leadership; Reflections on learning and achieving level 5 by Jim Collins. Linezine; organizational readiness in turbulent times. Retrieved July 6, 2006 from http://www.linezine.com/7.1/interviews/jcbmgtgl.htm

Mayo, A. J., \& Nohria, N. (2005). In their time: The greatest business leaders of the Twentieth Century. Boston: Harvard Business School Press.

Merriam-Webster Online Dictionary. (2006a). Role model. Retrieved March 29, 2006 from http://www.m-w.com/dictionary/role\%20model

Merriam-Webster Online Dictionary. (2006b). Hero. Retrieved March 29, 2006 from http://www.mw.com/dictionary/hero

Murphey, T. (1996). Near peer role models. Teacher Talking to Teacher: Newsletter of the Japan Association for language teaching, 4(3), 21 - 23.

NAA. (2006a). Awards, 1973 Senator Barry M. Goldwater. Retrieved March 31, 2006 from http://www.naa.aero/html/awards/index.cfm?cmsid=205.

NAA. (2006b). Wright Brothers Memorial Trophy. Retrieved March 30, 2006, from http://www.naa.aero/html/awards/index.cfm?cmsid=73

NAA. (2006c). Selection Committee. Retrieved March 31, 2006 from http://www.naa.aero/html/awards/index.cfm?cmsid=201

Reed, D. (2003, April 25). Carty resigns as 2 unions agree to new concessions. USATODAY. Retrieved July 4, 2006, from http://www.usatoday.com/travel/news/2003/2003-04-25-aa-cover.htm

Sanchez, T. R. (2000). It's time again for heroes—or were they ever gone? The Social Studies, 91 (2), 58 - 61. Retrieved from New FirstSearch April 20, 2004.

Sehgal, S. (2004). Carter award gives partnership role models to universities and communities. Campus Compact Reader - Fall 2004. Retrieved July 3, 2006 from http://www.compact.org/reader/fall04/ article1.html

Southwest Airlines. (2004, June). Southwest and TWU Local 556 reach tentative agreement. The Southwest Wing: A publication of Southwest Airlines governmental affairs department, 2(4). Retrieved July 21, 2006 from http://www.swatakeoff.com/swatakeoff/southwest_wing_0406.pdf

Time. (2005). Time 100: The most important people of the century. Retrieved July 22 from http://www.time.com/time/time100/

Titus, J. (2000). Where are the Heroes? Test and Measurement World, 10(5). Retrieved from EBSCO Research Databases February 6, 2006.

Trautvetter, C. (2004, October 4). Aviation International News - Eclipse chief stands by VLJ air-limo concept. Retrieved July 21, 2005 from http://www.eclipseaviation.com/inthenews/detail_04.htm

Verlander, E. G. (1985, April). The system's the thing. Training and Development Journal. 20 - 23.

Wells, A. T., \& Wensveen, J. G. (2004). Air transportation: A management perspective (5 ${ }^{\text {th }}$ ed.). Belmont, CA: Thomson.

Wings Club. (2006). Officers. Retrieved March 29, 2006 from http://www.wingsclub.org/officers.html

Wings Club. (2005). A brief history of the Wings Club. Retrieved July 25, 2005 from http://www.wingsclub.org

WordReference.com English Dictionary. (2006). Role model. Retrieved March 29 from http://www.wordreference.com/definition/role_model 


\section{APPENDIX A}

Past recipients of the Wings Club Distinguished Achievement Award

\begin{tabular}{|c|c|c|c|}
\hline Year & Recipient & Year & Recipient \\
\hline 2005 & Sir Richard Branson & 1990 & Armin O. Baltensweiler \\
\hline 2004 & Gordon Bethune & 1989 & Thomas H. Davis \\
\hline 2003 & $\begin{array}{l}\text { Brigadier General Charles } \\
\text { E. Yeager }\end{array}$ & 1988 & $\begin{array}{l}\text { The Flight Safety } \\
\text { Foundation }\end{array}$ \\
\hline 2002 & Sir Ralph Robins & 1987 & $\begin{array}{l}\text { Pioneer Trans-Atlantic } \\
\text { European Passenger } \\
\text { Carriers }\end{array}$ \\
\hline 2001 & Harry Stonecipher & 1986 & T.A. Wilson \\
\hline 2000 & Jean Pierson & 1985 & $\begin{array}{l}\text { The National Air \& Space } \\
\text { Museum of the } \\
\text { Smithsonian Institution }\end{array}$ \\
\hline 1999 & John H. Glenn, Jr. & 1984 & James M. Beggs \\
\hline 1998 & $\begin{array}{l}\text { Lord Marshall of } \\
\text { Knightsbridge }\end{array}$ & 1983 & $\begin{array}{l}\text { John C. Bierwirth } \\
\text { Thomas V. Jones } \\
\text { David S. Lewis, Jr. } \\
\text { Sanford N. McDonnell }\end{array}$ \\
\hline 1997 & U.S. Air Force & 1982 & $\begin{array}{l}\text { Senator Barry M. } \\
\text { Goldwater }\end{array}$ \\
\hline 1996 & Herbert D. Kelleher & 1981 & $\begin{array}{l}\text { Olive Ann Beech } \\
\text { Harry B. Combs } \\
\text { Leroy R. Grumman } \\
\text { William T. Piper, Jr. } \\
\text { Dwane L. Wallace } \\
\end{array}$ \\
\hline 1994 & $\begin{array}{l}\text { Cessna Citation Special } \\
\text { Olympics Airlift } \\
\text { Corporate Angel Network } \\
\text { ORBIS International } \\
\text { Wings of Hope }\end{array}$ & 1980 & $\begin{array}{l}\text { Sir Frank Whittle } \\
\text { Dr. Hans von Ohain } \\
\text { Sir Stanley G. Hooker } \\
\text { Jack S. Parker } \\
\text { Arthur E. Smith } \\
\end{array}$ \\
\hline 1993 & Robert L. Crandall & 1979 & $\begin{array}{l}\text { William M. Allen } \\
\text { Donald W. Douglas, Sr. } \\
\text { Hall L. Hibbard }\end{array}$ \\
\hline 1992 & $\begin{array}{l}\text { Frederick W. Smith and } \\
\text { the 95,000 Employees of } \\
\text { Federal Express Corp. }\end{array}$ & 1978 & $\begin{array}{l}\text { William A. Patterson } \\
\text { Robert F. Six } \\
\text { Cyrus R. Smith } \\
\text { Juan T. Trippe }\end{array}$ \\
\hline 1991 & Aviation Test Pilots & & \\
\hline
\end{tabular}




\section{APPENDIX B}

Wright Brothers Memorial Trophy Past Recipients

\begin{tabular}{|l|l|c|l|}
\hline Year & \multicolumn{1}{|c|}{ Recipient } & Year & \multicolumn{1}{|c|}{ Recipient } \\
\hline 2005 & Pete Aldridge & 1990 & Edwin I. Colodny \\
\hline 2004 & Bob Crandall & 1989 & Thomas Jones \\
\hline 2003 & Senator John Glenn & 1988 & Sam B. Williams \\
\hline 2002 & Paul Poberezny & 1987 & Allen E. Paulson \\
\hline 2001 & Neil A. Armstrong & 1986 & Joseph F. Sutter \\
\hline 2000 & Herb Kelleher & 1985 & Harry B. Combs \\
\hline 1999 & Delford M. Smith & 1984 & David S. Lewis \\
\hline 1998 & Edward Stimpson & 1983 & J. Leland Atwood \\
\hline 1997 & Charles H. Kaman & 1982 & Dr. Willis M. Hawkins \\
\hline 1996 & Frederick W. Smith & 1981 & Dwayne L. Wallace \\
\hline 1994 & Russell W. Meyer, Jr. & 1980 & Olive Ann Beech \\
\hline 1993 & A. L. Ueltschi & 1979 & T. A. Wilson \\
\hline 1992 & Gerhard Neumann & 1978 & Senator Jennings Randolph \\
\hline 1991 & Senator Jake Garn & & \\
\hline
\end{tabular}

APPENDIX C

W. A. Patterson Lecturers, Northwestern University Transportation Center

\begin{tabular}{|c|l|l|}
\hline Year & \multicolumn{1}{|c|}{ Speaker } & \multicolumn{1}{c|}{ Title and Sources } \\
\hline 2005 & Lawrence D. Burns & Vice President Research Development \& Planning, GMC \\
\hline 2004 & Michael L. Eskew & Chairman and CEO United Parcel Service, Inc. \\
\hline 2003 & David Neeleman & Chief Executive Officer and Director JetBlue Airways \\
\hline 2002 & Norman Y. Mineta & Secretary U.S. Department of Transportation \\
\hline 2001 & Donald Schneider & President Schneider National, Inc. \\
\hline 2000 & Frederick W. Smith & $\begin{array}{l}\text { Chairman, President and Chief Executive Officer FedEx } \\
\text { Corporation }\end{array}$ \\
\hline 1999 & Robert Krebs & $\begin{array}{l}\text { Chairman, President, CEO; Burlington Northern Sante FE } \\
\text { Railway }\end{array}$ \\
\hline 1998 & Lua Cheng Eng & Deputy Chairman, President and CEO; Neptune Orient Ltd \\
\hline 1997 & Herb Kelleher & Chairman, President and CEO Southwest Airline Company \\
\hline 1996 & John Welsby & Chairman and Chief Executive Officer British Railways \\
\hline 1995 & William ("Gus") Pagonis & Sr. VP, Logistics, Sears, Roebuck \\
\hline 1994 & Karel Van Miert & Commissioner of Competition for the European Union \\
\hline 1993 & Dr. Robert Herman, L.P. & $\begin{array}{l}\text { Gilvin Centennial Professor Emeritus Civil Engineering; } \\
\text { University of Texas Austin }\end{array}$ \\
\hline 1992 & J.B. Hunt & Chairman of the Board J.B. Hunt Transport, Inc. \\
\hline 1991 & Heinz Ruhnau & Chairman Lufthansa German Airlines \\
\hline 1990 & Donald (Deke) K. Slayton & Astronaut, President and Vice Chairman Space Services \\
\hline 1989 & Sir Colin Marshall & Chief Executive Officer British Airways \\
\hline
\end{tabular}




\begin{tabular}{|c|l|l|}
\hline 1988 & William W. Winpisinger & $\begin{array}{l}\text { International President International Association of Machinists and } \\
\text { Aerospace Workers }\end{array}$ \\
\hline 1987 & Frank Lorenzo & $\begin{array}{l}\text { Chairman, President and Chief Executive Officer Texas Air } \\
\text { Corporation }\end{array}$ \\
\hline 1986 & Robert L. Crandall & $\begin{array}{l}\text { Chairman and President AMR Corporation and American Airlines, } \\
\text { Inc. }\end{array}$ \\
\hline 1985 & Marvin L. Manheim & William A. Patterson Distinguished Professor \\
\hline 1984 & Dr. Daryl Wyckoff & James J. Hill Professor of Transportation Harvard U. \\
\hline 1982 & Alfred E. Kahn & Professor of Economics Cornell U. \\
\hline 1980 & Richard J. Ferris & Chairman and CEO United Airlines \\
\hline
\end{tabular}

\section{APPENDIX D}

CNN Top 25 Influential Business Leaders

\begin{tabular}{|c|l|l|}
\hline 1 & Bill Gates & co-founder of Microsoft \\
\hline 2 & Sam Walton & former CEO of Wal-Mart \\
\hline 3 & Jack Welch & former CEO of General Electric \\
\hline 4 & Warren Buffett & CEO of Berkshire Hathaway \\
\hline 5 & Lee Iacocca & former CEO of Chrysler \\
\hline 6 & Steve Jobs & CEO of Apple \\
\hline 7 & Herb Kelleher & chairman of Southwest Airlines \\
\hline 8 & Michael Dell & founder of Dell Computer \\
\hline 9 & Alan Greenspan & chairman of the Federal Reserve Board \\
\hline 10 & Carl Icahn & 1980 s corporate raider \\
\hline 11 & Andy Grove & former CEO of Intel \\
\hline 12 & Michael Milken & former junk-bond wizard \\
\hline 13 & John Reed & former CEO of Citigroup \\
\hline 14 & Ted Turner & founder of CNN \\
\hline 15 & Jim Clark & former CEO of Netscape \\
\hline 16 & Marge Whitman & CEO of eBay \\
\hline 17 & Jeff Bezos & founder of Amazon.com \\
\hline 18 & Michael Eisner & CEO of Disney \\
\hline 19 & Peter Lynch & manager of Fidelity's Magellan Fund \\
\hline 20 & Phil Knight & CEO of Nike \\
\hline 21 & Katharine Graham & late CEO of Washington Post Co. \\
\hline 22 & W. Edwards Deming & influential business consultant \\
\hline 23 & Ken Lay & former CEO of Enron \\
\hline 24 & Shawn Fanning & founder of Napster \\
\hline 25 & Lou Gerstmer & former CEO of IBM \\
\hline & Lst puished Jne 9,2005, & avain rela \\
\hline
\end{tabular}

List published June 19, 2005, aviation related individuals emphasized. 


\section{APPENDIX E}

Harvard Business School 20 $0^{\text {th }}$ Century Great American Business Leaders - Transportation

\begin{tabular}{|c|c|c|}
\hline & Name & Aviation Company \\
\hline 1 & Bethune, Gordon M. & Continental 1994 - 2004 \\
\hline 2 & Budd, Ralph & \\
\hline 3 & Burr, Donald C. & People Express 1980 - 1986 \\
\hline 4 & Carlson, Edward E. & United Airlines 1971 - 1979 \\
\hline 5 & Casey, James E. & UPS 1907 - 1962 \\
\hline 6 & Clement, Martin W. & \\
\hline 7 & Crandall, Robert L. & American Airlines 1985 - 1998 \\
\hline 8 & Emery, Jr., John C. & Emery Air Freight 1968 - 1987 \\
\hline 9 & Emery, Sr., John C. & Emery Air Freight 1946 - 1967 \\
\hline 10 & Flagler, Henry M. & \\
\hline 11 & Franklin, John M. & \\
\hline 12 & Frye, Jack & Trans World Airlines 1934 - 1947 \\
\hline 13 & Gray, Carl R. & \\
\hline 14 & Hill, James J. & \\
\hline 15 & Hill, Louis W. & \\
\hline 16 & Holden, Hale & \\
\hline 17 & Kelleher, Herbert D. & Southwest Airlines 1967 - 2001 \\
\hline 18 & Lorenzo, Francisco A. & Texas Air Company $1972-1990$ \\
\hline 19 & Luckenbach, Jr., Edgar F. & \\
\hline 20 & Ludwig, Daniel K. & \\
\hline 21 & Mallory, Clifford D. & \\
\hline 22 & Mallory, Henry R. & \\
\hline 23 & McLean, Malcolm P. & \\
\hline 24 & Norris, Ernest E. & \\
\hline 25 & Nyrop, Donald W & Northwest Airlines 1954 - 1978 \\
\hline 26 & Patterson, William A. & United Airlines 1934 - 1963 \\
\hline 27 & Rentschler, Frederick B. & United Aircraft 1928 - 1934 \\
\hline 28 & Rickenbacker, Edward V. & Eastern Airlines 1938 - 1953 \\
\hline 29 & Shoen, Leonard S. & \\
\hline 30 & Six, Robert F. & Continental Airlines 1907 - 1986 \\
\hline 31 & Sloan, Matthew S. & \\
\hline 32 & Smith, Cyrus R. & American Airlines 1934 - 1968 \\
\hline 33 & Smith, Frederick W. & Federal Express 1973 - \\
\hline 34 & Spencer, Samuel & \\
\hline 35 & Trippe, Juan T. & Pan American World Airways 1927 - 1969 \\
\hline 36 & Underwood, Frederick D. & \\
\hline 37 & Vauclain, Samuel M. & \\
\hline 38 & Wallace, James C. & \\
\hline 39 & Warfield, Solomon D. & \\
\hline 40 & Wickman, Carl E. & \\
\hline 41 & Willard, Daniel & \\
\hline 42 & Young, Robert R. & \\
\hline
\end{tabular}

Aviation related individuals emphasized. 


\section{APPENDIX F}

Harvard Business School $20^{\text {th }}$ Century Great American Business Leaders - Automotive and Aerospace

\begin{tabular}{|c|c|c|}
\hline & Name & Aviation Company \\
\hline 1 & Allen, William M. & Boeing 1945 - 1969 \\
\hline 2 & Beals, Jr., Vaughn L. & \\
\hline 3 & Beech, Olive Ann M. & Beech Aircraft Corporation 1950 - 1968 \\
\hline 4 & Blumenthal, W. Michael & \\
\hline 5 & Boeing, William E. & Boeing Company 1916 - 1934 \\
\hline 6 & Bossidy, Lawrence A. & \\
\hline 7 & Braniff, Thomas E. & Braniff Airlines 1930 - 1954 \\
\hline 8 & Budd, Edward G. & \\
\hline 9 & Caldwell, Philip & \\
\hline 10 & Chapin, Roy D. & \\
\hline 11 & Chrysler, Walter P. & \\
\hline 12 & Collyer, John L. & \\
\hline 13 & Crawford, Frederick C. & \\
\hline 14 & Crosby, Joseph W. & Thiokol Corporation 1947 - 1963 \\
\hline 15 & Curtice, Harlow H. & \\
\hline 16 & Davis, Charles S. & \\
\hline 17 & Donner, Frederic G. & \\
\hline 18 & Douglas, Donald W. & Douglas Aircraft Company 1928 - 1957 \\
\hline 19 & Durant, William & \\
\hline 20 & Eaton, Robert J. & \\
\hline 21 & Emanuel, Victor & $\begin{array}{l}\text { AVCO } 1939-1960 \text { Aircraft and ship } \\
\text { manufacturing. }\end{array}$ \\
\hline 22 & Firestone, Harvey S. & \\
\hline 23 & Firestone, Jr., Harvey S. & \\
\hline 24 & Fisher, Frederick J. & \\
\hline 25 & Ford, Henry & \\
\hline 26 & Ford II, Henry & \\
\hline 27 & Gross, Robert E. & Lockheed Aircraft Corporation 1934 - 1956 \\
\hline 28 & Hertz, John D. & \\
\hline 29 & Hoffman, Paul G. & \\
\hline 30 & Hughes, Jr., Howard R. & Hughes Aircraft Company 1933 - 1976 \\
\hline 31 & Iacocca, Lido (Lee) A. & \\
\hline 32 & Joy, Henry B. & \\
\hline 33 & Keller, Kaufman T. & \\
\hline 34 & Lamm, Harvey H. & \\
\hline 35 & Lear, William P. & Lear 1939 - 1967 \\
\hline
\end{tabular}

Continued on next page. 


\section{APPENDIX F CONTINUED}

\begin{tabular}{|c|c|c|}
\hline 36 & Litchfield, Paul W. & \\
\hline 37 & Martin, Glenn L. & Glenn L. Martin Company 1907 - 1949 \\
\hline 38 & McDonnell, James S. & McDonnell Aircraft Corporation 1939 - 1967 \\
\hline 39 & McPherson, Rene C. & \\
\hline 40 & Mott, Charles S. & \\
\hline 41 & Nash, Charles W. & \\
\hline 42 & Northrop, John K. & Northrop Aircraft 1937 - 1959 \\
\hline 43 & Olds, Ransom E. & \\
\hline 44 & Peppiatt, Guy S. & \\
\hline 45 & Petersen, Donald E. & \\
\hline 46 & Pigott, Charles M. & \\
\hline 47 & Prince, Larry L. & \\
\hline 48 & Ramo, Simon & $\begin{array}{l}\text { Thompson-Ramo-Wooldridge Corp. } 1953 \text { - 1958, } \\
\text { Military missile and other control systems. }\end{array}$ \\
\hline 49 & Rockwell, Willard F. & \\
\hline 50 & Rockwell, Jr., Willard F. & \\
\hline 51 & Seiberling, Frank A. & \\
\hline 52 & Sikorsky, Igor I. & Sikorsky Aircraft 1923 - 1957 \\
\hline 53 & Sloan, Jr., Alfred P. & \\
\hline 54 & Smith, Roger B. & \\
\hline 55 & Stranahan, Jr., Robert A. & \\
\hline 56 & Trotman, Alex & \\
\hline 57 & Vaughan, Guy W. & Curtiss-Wright Aircraft Company 1935 - 1949 \\
\hline 58 & Wallace, Dwane L. & Cessna Aircraft Company 1936 - 1975 \\
\hline 59 & Wilson, Charles Erwin & \\
\hline 60 & Wilson, Thornton A. & Boeing Company 1969 - 1986 \\
\hline
\end{tabular}

Aviation related individuals emphasized. 


\section{APPENDIX G}

Top 50 Business Leaders of the $20^{\text {th }}$ Century

\begin{tabular}{|c|c|}
\hline 1 & Samuel M. Walton, Wal-Mart \\
\hline 2 & Walter E. Disney, Walt Disney \\
\hline 3 & William H. Gates III, Microsoft \\
\hline 4 & Henry Ford, Ford Motor \\
\hline 5 & John P. Morgan, J.P. Morgan Chase \\
\hline 6 & Alfred P. Sloan Jr., General Motors \\
\hline 7 & John F. Welch Jr., General Electric \\
\hline 8 & Raymond A. Kroc, McDonald's \\
\hline 9 & William R. Hewlett, Hewlett-Packard \\
\hline 10 & David Packard, Hewlett-Packard \\
\hline 11 & Andrew S. Grove, Intel \\
\hline 12 & Milton S. Hershey, The Hershey Co. \\
\hline 13 & John D. Rockefeller Sr., Standard Oil \\
\hline 14 & Thomas J. Watson Jr, IBM \\
\hline 15 & Henry R. Luce, Time-Life Publications \\
\hline 16 & Will K. Kellogg, Kellogg \\
\hline 17 & Warren E. Buffett, Berkshire Hathaway \\
\hline 18 & $\begin{array}{l}\text { Harland Sanders, Kentucky Fried } \\
\text { Chicken }\end{array}$ \\
\hline 19 & William C. Procter, Procter \& Gamble \\
\hline 20 & Thomas J. Watson Sr., IBM \\
\hline 21 & Asa G. Candler, Coca-Cola \\
\hline 22 & Estee Lauder, Estee Lauder \\
\hline 23 & Henry J. Heinz, H.J. Heinz \\
\hline 24 & Daniel F. Gerber Jr., Gerber Products \\
\hline 25 & James L. Kraft, Kraft Foods \\
\hline
\end{tabular}

\begin{tabular}{|c|c|}
\hline 26 & Steven P. Jobs, Apple Computer \\
\hline 27 & John T. Dorrance, Campbell Soup \\
\hline 28 & Leon L. Bean, LL Bean \\
\hline 29 & William Levitt, Levitt \& Sons \\
\hline 30 & Howard Schultz, Starbucks \\
\hline 31 & Michael Dell, Dell Computer \\
\hline 32 & Robert W. Johnson Jr., Johnson \& Johnson \\
\hline 33 & James E. Casey, United Parcel Service \\
\hline 34 & Herbert D. Kelleher, Southwest Airlines \\
\hline 35 & George Eastman, Eastman Kodak \\
\hline 36 & Philip H. Knight, Nike \\
\hline 37 & James O. McKinsey, McKinsey \& Co. \\
\hline 38 & Charles R. Schwab, Charles Schwab \\
\hline 39 & Frederick W. Smith, Federal Express \\
\hline 40 & William Wrigley Jr., Wm. Wrigley Jr. Co. \\
\hline 41 & Gordon E. Moore, Intel \\
\hline 42 & $\begin{array}{l}\text { Robert (Ted) E. Turner, } \\
\text { Turner Broadcasting }\end{array}$ \\
\hline 43 & J. Willard Marriott Jr., Marriott Int'l. \\
\hline 44 & James E. Burke ,Johnson \& Johnson \\
\hline 45 & David Sarnoff, RCA \\
\hline 46 & William E. Boeing, Boeing \\
\hline 47 & Walter A. Haas Sr., Levi Strauss \\
\hline 48 & Henry J. Kaiser, Kaiser Industries \\
\hline 49 & Walter A. Haas Jr. ,Levi Strauss \\
\hline 50 & Clarence Birdseye, Bird's Eye Foods \\
\hline
\end{tabular}

Aviation related individuals emphasized. 